\title{
SOME ISSUES OF GRANTING PUBLICLY AND MUNICIPALLY OWNED LAND PLOTS TO A NON-PROFIT ORGANIZATION FOR GARDENING AND VEGETABLE GROWING
}

\author{
Alina V. Zhuleva \\ Saratov State Law Academy, Saratov, Russian Federation
}

Introduction: the major transformations in the field of land law that took place in Russia in 2014 touched upon the issues of providing the citizens and legal entities with publicly or municipally owned land plots. This topic is relevant today, as with the help of the state-provided garden, vegetable, suburban land plots, the citizen's right to rest is exercised, as well as getting environmentally friendly agricultural products for their own needs is provided.

Methods: the methodological framework for this study is a set of methods of scientific knowledge, among which the main are the comparative law method and the analysis of the legal framework.

Results: the author's point of view shown in the work is based on the legislation and the opinions of the competent academic community on the provision of publicly or municipally owned land plots to a non-profit organization for gardening and vegetable growing. On the basis of introducing the novelties in the land legislation connected with granting of lands to the gardeners and vegetable growers, the analysis and comparison with the previous legislation is given.

Conclusions: the study identified the positive aspects of the new law and the negative aspects of the previous legislation. In this regard, it is concluded that the current conditions for the development of society and state require that the adopted laws not only solve the existing problems of gardeners, vegetable growers and cottagers, but also become the basis for the development and improvement of their legal culture, as well as the convergence of their interests with the interests of the public authorities in the use of the land resources.

Key words: granting land plots for gardening and vegetable growing, non-profit organizations, free of charge, free use, state and municipal property, land reform, Federal law of 15 April 1998 No. 66-FZ, Federal law of 29 July 2017 No. 217-FZ.

Citation. Zhuleva A.V. Some Issues of Granting Publicly and Municipally Owned Land Plots to a Non-Profit Organization for Gardening and Vegetable Growing. Legal Concept, 2018, vol. 17, no. 4, pp. 103-107. DOI: https:// doi.org/10.15688/lc.jvolsu.2018.4.14

\section{НЕКОТОРЫЕ ПРОБЛЕМЫ ПРЕДОСТАВЛЕНИЯ ЗЕМЕЛЬНЫХ УЧАСТКОВ, НАХОДЯЩИХСЯ В ГОСУДАРСТВЕННОЙ И МУНИЦИПАЛЬНОЙ СОБСТВЕННОСТИ, НЕКОММЕРЧЕСКОЙ ОРГАНИЗАЦИИ ДЛЯ ВЕДЕНИЯ САДОВОДСТВА И ОГОРОДНИЧЕСТВА}


зуется право гражданина на отдых, а также обеспечивается получение экологически чистой сельскохозяйственной продукции для собственных нужд.

Методы: методологическую основу данного исследования составляет совокупность методов научного познания, среди которых основное место занимают сравнительно-правовой метод и анализ нормативноправовой базы.

Результаты: обоснованная в работе авторская позиция опирается на законодательство и мнения компетентной научной среды по вопросу предоставления земельных участков, находящихся в государственной и муниципальной собственности, некоммерческой организации для ведения садоводства и огородничества. На основании введения новелл в земельном законодательстве, связанных с предоставлением земель огородникам и садоводам, дается анализ и сравнение с предшествующим законодательством.

Выводы: в результате исследования выявлены положительные нового и отрицательные стороны предшествующего законодательства. В связи с этим делается вывод о том, что современные условия развития общества и государства требуют, чтобы принимаемые законы не только решали существующие проблемы садоводов, огородников и дачников, но и стали основой развития и повышения уровня их правовой культуры, а также сближения их интересов с интересами органов публичной власти в вопросе использования земельных ресурсов.

Ключевые слова: предоставление земельных участков для садоводства и огородничества, некоммерческие организации, бесплатно, безвозмездное пользование, государственная и муниципальная собственность, земельная реформа, Федеральный закон от 15.04.1998 № 66-Ф3, Федеральный закон от 29.07.2017 № 217-Ф3.

Цитирование. Жулева А. В. Некоторые проблемы предоставления земельных участков, находящихся в государственной и муниципальной собственности, некоммерческой организации для ведения садоводства и огородничества // Legal Concept = Правовая парадигма. -2018 . - T. 17, № 4. - C. 103-107. - DOI: https:// doi.org/10.15688/lc.jvolsu.2018.4.14

\section{Введение}

Крупнейшие преобразования в сфере земельного права, произошедшие в России в 2014 г. затронули вопросы предоставления гражданам и юридическим лицам земельных участков, находящихся в государственной или муниципальной собственности. Положения Федерального закона от 23.06.2014 № 171-Ф3 «О внесении изменений в Земельный кодекс Российской Федерации и отдельные законодательные акты Российской Федерации» (далее - Закон № 171-Ф3) в корне изменили порядок предоставления земельных участков, находящихся в государственной или муниципальной собственности. Способствовало данным концептуальным изменениям поручение Президента Российской Федерации от 26.10.2012 № Пр-2869 по итогам заседания президиума Государственного совета Российской Федерации 09.10.2012 «О повышении эффективности управления земельными ресурсами в интересах граждан и юридических лиц», а также Послание Президента Российской Федерации Федеральному Собранию от 12.12.2013 «Основы государственной политики использования земельного фонда Российской Федерации на 2012-2020 годы».
Одним из случаев предоставления земельного участка, находящегося в государственной и муниципальной собственности, гражданину или юридическому лицу в собственность бесплатно согласно ст. 39.5 Земельного кодекса Российской Федерации от 25.10.2001 № 136-Ф3 (ред. от 03.08.2018) является предоставление земельного участка, образованного в результате раздела, предоставленного некоммерческой организации, созданной гражданами, для ведения садоводства и огородничества.

Данная тема является актуальной, так как с помощью садовых, огородных, дачных земельных участков реализуется право гражданина на отдых, обеспечивается получение экологически чистой сельскохозяйственной продукции для собственных нужд, осуществляется развитие инфраструктуры муниципальных образований. По мнению И.А. Бутовецкого, садоводческие, огороднические и дачные некоммерческие объединения граждан создаются также для содействия в решении задач, связанных не только с их материальными потребностями, но и в целях духовного и физического развития, в том числе и подрастающего поколения [3]. С данной точкой зрения нельзя не согласиться, так как 
она отражает понимание основной задачи гражданского общества - возможности реализации социальных и экономических интересов личности.

\section{Сравнительный анализ Федерального закона от 15.04.1998 № 66-Ф3 и Федерального закона от 29.07.2017 № 217}

В настоящее время предоставление земельного участка некоммерческой организации для ведения садоводства и огородничества регламентируется ст. 14 Федерального закона от 15.04.1998 № 66-Ф3 (ред. от 03.07.2016) «О садоводческих, огороднических и дачных некоммерческих объединениях граждан» (далее - Ф3 № 66-Ф3), который утрачивает силу с 1 января 2019 г. в связи с изданием Федерального закона от 29.07.2017 № 217 «О ведении гражданами садоводства и огородничества для собственных нужд и о внесении изменении в отдельные законодательные акты Российской Федерации» (далее - Ф3 № 217-Ф3).

Согласно ст. 13 Ф3 № 66-Ф3 определение потребности в земельных участках, а также обеспечение граждан садовыми, огородными и дачными земельными участками лежит на органах местного самоуправления по месту жительства граждан. Следовательно, за учет заявлений, их регистрацию и установление на очередность предоставления земельных участков по вышеуказанному закону отвечают те же органы.

В связи изменениями в Российском законодательстве с 1 марта 2015 г. проблема нуждающихся в садовых и огородных участках, а также вопрос включения таких лиц в список нуждающихся в получении земли для огородного и садового хозяйства во многом утратил свою актуальность, в связи с закреплением на федеральном уровне в ст. 39.639 .18 ЗК РФ положений, касающихся порядка предоставления земельных участков гражданам, не являющихся членами некоммерческих объединений.

В соответствии с подп. 11 п. 2 ст. 39.10 Земельного кодекса Российской Федерации предоставление земельных участков некоммерческим организациям, созданным гражда- нами для ведения садоводства и огородничества, осуществляется на праве безвозмездного пользования сроком не более пяти лет.

Некоммерческим организациям за отведенный период необходимо обеспечить подготовку в отношении соответствующего земельного участка необходимых документов: проектов планировки и межевания территории, а также проведение кадастровых работ. И.Ф. Саматов и А.В. Алиферова поддерживают данные законодательные положения, так как подготовка документации требует от объединений поиск денежных средств, являющихся источниками арендной уплаты [2; 4].

С принятием изменений в земельном законодательстве в 2015 г. преобразовался и порядок предоставления земельных участков для садоводов и огородников за плату, регулируемый п. 2 ст. 11.10 ЗК РФ. Теперь лица, имеющие садовой и огородное хозяйство, в том числе создавшие юридическое лицо, имеют право подготовить схему расположения земельного участка на кадастровом плане территории, если нет утвержденного проекта межевания территории. После вышеуказанных действий садоводы и огородники имеют право обратиться с заявлением о предоставлении интересующего их земельного участка.

Сама процедура приобретения садовых, огородных и дачных земельных участков членами вновь создаваемых объединений конкретизировалась в положениях, регламентируемых п. 4 ст. 14 Закона № 66-ФЗ. В связи с этим в правоприменительной практике возникало немало внутренних противоречий вследствие отсутствия законодательного закрепления определения: вид права, на котором земельный участок мог быть предоставлен бесплатно вновь созданным объединениям граждан; порядок «последующего» предоставления садовых, огородных и дачных земельных участков членам объединения при предоставлении их за плату.

\section{Порядок предоставления \\ земельных участков нуждающимся категориям граждан}

Новый, начинающий действовать с 1 января 2019 г. ФЗ № 71-Ф3, по сравнению с пре- 
дыдущими законами, не оставляет без внимания такие проблемы, как сроки рассмотрения и принятия решений по заявлениям о предоставлении земельных участков без проведения торгов, перечень документов, необходимых для предоставления садовых, огородных и дачных земельных участков. Указанный список документов утвержден Приказом Министерства экономического развития Российской Федерации от 12.01.2015 № 1 «Об утверждении перечня документов, подтверждающих право заявителя на приобретение земельного участка без проведения торгов».

Предоставление садовых, огородных или дачных земельных участков одной из категории нуждающихся в таких участках регламентируется ст. 34 Закона № 171-ФЗ Федеральным законом от 12.01.1995 № 5-Ф3 (ред. от 29.07.2018) «О ветеранах». Вместе с тем нельзя забывать, что само по себе включение гражданина в список нуждающихся и раньше не являлось гарантией приобретения участка в дальнейшем.

Так, специалистами указывалось, что норму об обязанности органов местного самоуправления обеспечить граждан по первому их требованию дачными, садовыми или огородными земельными участками не следует понимать буквально. Кроме желания граждан и органов местного самоуправления исполнить соответствующие требования, для этого должны быть объективные условия. Под последними понимается наличие в муниципальном образовании свободных от прав третьих лиц земельных участков, находящихся в государственной или муниципальной собственности, которые в соответствии с градостроительной документацией (генеральным планом и правилами землепользования и застройки) предназначены для предоставления гражданам для ведения садоводства, огородничества и дачного хозяйства. Отмечалась совершенно обычная ситуация (особенно в условиях крупного города), когда орган местного самоуправления не располагает такими участками, поскольку все свободные (незастроенные) территории запланированы под жилую, общественно-деловую и иную застройку [1].

\section{Заключение}

Необходимо отметить, что Земельная реформа продолжает проводится по сегодняшний день. На законодательном фронте ведутся научные дискуссии, продолжается полемика, а также не стихают законотворческие процессы по поводу внесения изменений в законодательные акты не только на Федеральном, но и местном уровне касающиеся предоставления земель для садоводства и огородничества. Изменения, проводимые в законодательстве России в 2015 году. Произошедшая в марте 2015 г. реформа имела целью структурирование и упорядочивание многообразия трактовок старой редакции закона, а также создания такой системы земельных правоотношений, которая бы максимально отвечала бы не только сложившимся процессам в этой области, но и предвидела развитие земельных отношений в будущем. Безусловно, к положительным моментам преобразования земельного законодательства в области предоставления земельных участков для садоводства и огородничества можно отнести упрощение процедуры предоставления земель,скурпулезное продумываниетребований к организации некоммерческих объединений граждан, более правильное распределение полномочий по сравнению с прежними редакциями, а также реализацию ряда идей, способствующих повышению качества законодательства и доступность земельных ресурсов для садоводов, огородников и дачников.

В связи с этим нельзя не признать, что современные условия развития общества и государства требуют, чтобы принимаемые законы не только решали существующие проблемы садоводов, огородников и дачников, но и стали основой развития и повышения уровня их правовой культуры, а также сближения их интересов с интересами органов публичной власти в вопросе использования земельных ресурсов.

\section{СПИСОК ЛИТЕРАТУРЫ}

1. Анисимов, А. П. Постатейный комментарий к Федеральному закону «О садоводческих, огороднических и дачных некоммерческих объедине- 
ниях граждан» / А. П. Анисимов, Ю. В. Васильчук, А. Ю. Чикильдина. - М. : ГроссМедиа : РОСБУХ, 2008. $-304 \mathrm{c}$.

2. Алиферова, А. В. Особенности формирования земельного участка для размещения садоводческого товарищества в России в разные периоды земельного законодательства / А. В. Алиферова // Проблемы геологии и освоения недр : тр. ХХ Междунар. симпоз. им. акад. М.А. Усова студентов и молодых ученых, посвящ. 120-летию со дня основания Томск. политех. ун-та (Томск, 4-8 апреля 2016 г.) : в 2 т. - Томск : Изд-во ТПУ, 2016. - T. 1. - С. 728-730.

3. Бутовецкий, И. А. Предоставлениеземельных участков для ведения садоводства, огородничества и дачного хозяйства в свете земельной реформы / И. А. Бутовецкий // Имущественные отношения в Российской Федерации. - 2015. - № 10. - С. 80-96.

4. Саматов, И. Ф. Правоприменительная практика предоставления земельных участков объединениям садоводов, огородников и дачников / И. Ф. Саматов // Научное сообщество студентов: Междисциплинарные исследования : сб. ст. по материалам XXXV Междунар. студ. науч.-практ. конф. - № 24 (35). С. 503-507. - Электрон. текстовые дан. - Режим доступа: https://sibac.info/archive/meghdis/24(35).pdf (дата обращения: 04.10.2018). - Загл. с экрана.

\section{REFERENCES}

1. Anisimov A.P., Vasilchuk Yu.V., Chikildina A.Yu. Postateynyy kommentariy $k$ Federalnomu zakonu «O sadovodcheskikh, ogorodnicheskikh $i$ dachnykh nekommercheskikh obyedineniyakh grazhdan» [By-Article Commentary to the Federal Law 'On Horticultural, Gardening and Rural NonCommercial Associations of Citizens']. Moscow, GrossMedia; ROSBUKh Publ., 2008. 304 p.
2. Aliferova A.V. Osobennosti formirovaniya zemelnogo uchastka dlya razmeshcheniya sadovodcheskogo tovarishchestva v Rossii v raznye periody zemelnogo zakonodatelstva [Land Plot Preparation for the Horticultural Association of Students and Young Scientists in Different Periods of Land Legislation]. Problemy geologii i osvoeniya nedr: tr. XX Mezhdunar. simpoz. im. akad. M.A. Usova studentov i molodykh uchenykh, posvyashch. 120-letiyu so dnya osnovaniya Tomsk. politekh. un-ta (Tomsk, 4-8 aprelya 2016 g.): $v 2 t$. [Problems of Geology and Subsoil Development: Proceedings of the $20^{\text {th }}$ International Symposium named after Academician M. A. Usov for Students and Young Scientists, Dedicated to the $120^{\text {th }}$ Anniversary of Tomsk Polytechnic University Foundation (Tomsk, 4-8 April 2016). In 2 vols.]. Tomsk, Izd-vo TPU, 2016, vol. 1, pp. 728-730.

3. Butovetskiy I.A. Predostavlenie zemelnykh uchastkov dlya vedeniya sadovodstva, ogorodnichestva i dachnogo khozyaystva v svete zemelnoy reformy [Provision of Land Plots for Gardening, Vegetable Gardening and Small-Scale Rural Construction in the Contetx of Land Reform]. Imushchestvennye otnosheniya $v$ Rossiyskoy Federatsii, 2015, no. 10, pp. 80-96.

4. Samatov I.F. Pravoprimenitelnaya praktika predostavleniya zemelnykh uchastkov obyedineniyam sadovodov, ogorodnikov i dachnikov [The Law Enforcement Practice of Providing Land Plots to Associations of Gardeners and Farmers]. Nauchnoe soobshchestvo studentov: Mezhdistsiplinarnye issledovaniya: sb. st. po materialam XXXV Mezhdunar. stud. nauch.-prakt. konf. № 24 (35) [Scientific Community of Students. Interdisciplinary Research. Collected Articles of the $35^{\text {th }}$ International Research and Practice Conference for Students, no. 24 (35)], pp. 503507. URL: https://sibac.info/archive/meghdis/24(35).pdf (accessed 4 October 2018).

\section{Information about the Author}

Alina V. Zhuleva, Postgraduate Student, Department of Land and Ecological Law, Saratov State Law Academy, Volskaya St., 1, 410056 Saratov, Russian Federation, levuazh@mail.ru, https:/orcid.org/ 0000-0003-3217-610X

\section{Информация об авторе}

Алина Валерьевна Жулева, аспирант кафедры земельного и экологического права, Саратовская государственная юридическая академия, ул. Вольская, 1, 410056 г. Саратов, Российская Федерация, levuazh@mail.ru, https://orcid.org/0000-0003-3217-610X 